\title{
ECOLOGY
}

\section{Development time plasticity of the pine processionary moth (Thaumetopoea pityocampa) populations under laboratory conditions}

\author{
L. Berardi, ${ }^{1}$ M. Branco, ${ }^{2}$ M.R. Paiva, ${ }^{3}$ H. Santos, ${ }^{2}$ A. Battisti ${ }^{1}$ \\ 'Department DAFNAE-Entomology, University of Padova, Legnaro, Italy; ${ }^{2}$ Department of Natural \\ Resources, Environment and Landscape, Instituto Superior de Agronomia, University of Lisbon, \\ Portugal; ${ }^{3}$ Department of Environmental Sciences and Engineering, Faculty of Sciences and \\ Technology, New University of Lisbon, Portugal
}

\begin{abstract}
The pine processionary moth Thaumetopoea pityocampa (Lepidoptera, Notodontidae) is a univoltine defoliator that is active over a wide range of latitudes and elevations, being largely influenced by temperature variations, especially during larval development across the winter. This work compares field development time with that observed in the laboratory rearing under controlled conditions, in four Th. pityocampa populations characterized by different life history phenology: two populations from the Italian Alps characterized by early and late adult emergence, and two populations from Portugal, the first characterized by winter feeding and late adult emergence, the second by a switch of the larval feeding from winter to summer. The rearing started from the egg stage and was maintained in the laboratory at $20-25^{\circ} \mathrm{C}$ under natural light in transparent boxes. In spite of the different geographic origins and asynchrony of the period of larval development, all populations maintained an annual life cycle under laboratory conditions, as well as a phenology similar to that
\end{abstract}

Correspondence: Laura Berardi, University of Padova, Department DAFNAEEntomology, Agripolis, Via dell'Università 16, 35020 Legnaro (PD), Italy. Tel.:+39.049.827.2804 - Fax: +39.049.827.2784.

E-mail: laura.berardi2@gmail.com

Key words: Notodontidae; development time; diapause; shift; rearing.

Acknowledgements: we warmly thank Salman Habibur Rahman and Mathieu Laparie for useful comments on an earlier version of the manuscript. This work was carried out in part with the grant $60 \%$ of the University of Padova.

Contributions: the authors contributed equally.

Conflict of interest: the authors declare no potential conflict of interest.

Received for publication: 13 March 2015.

Revision received: 19 August 2015

Accepted for publication: 24 August 2015.

This work is licensed under a Creative Commons Attribution NonCommercial 3.0 License (CC BY-NC 3.0).

(C) Copyright L. Berardi et al., 2015

Licensee PAGEPress, Italy

Entomologia 2015; 3:273

doi:10.4081/entomologia.2015.273 of the field populations. Such an outcome was possible due to a trade-off in the duration of the larval and pupal stages, the latter being identified as the phase of development when an efficient regulatory mechanism is acting to maintain the univoltine life cycle.

\section{Introduction}

Regulating phenology to be active and reproduce at the most favourable season is a common evolutionary mechanism in animals and plants (Tauber et al., 1986; Danks, 1987; Whitman \& Agrawal, 2009). Many insect species, in particular the herbivores, are univoltine and semelparous. The single reproductive event occurs normally in the season which allows for the optimization of offspring survival. Seasonality thus appears as a strong factor maintaining the univoltine cycle and insects use environmental variables to track the right time of activity (Saunders, 1982; Danks, 1987). For herbivore insects, the univoltine life cycle is often explained by a precise synchronization with a particular developmental phase of the host plant. For example, several early-feeding herbivores of temperate forest ecosystems depend on the ingestion of young foliage, which is available during a restricted time window in the spring, while less specialized feeders are less constrained in time and can develop over longer periods or alternatively become multivoltine (Dajoz, 2000). Evergreen coniferous host plants offer a good opportunity to test this hypothesis providing a relatively stable food supply i.e. mature leaves, which remain available year round. For example, in the diprionid sawflies, some species have a fixed univoltine cycle whereas others may have univoltine cycles interchanged with multivoltine ones (Larsson et al., 1993). The latter species when reared in the laboratory under optimal conditions of temperature and photoperiod may develop continuous generations, as in the case of Diprion pini (Eichhorn, 1976).

However, shifts in the phenology may occur in any life stage depending on alterations of the environmental parameters. Saunders (1982) showed that the effects of day length on the induction and termination of diapause may be modified by rising temperatures. This happens because the photoperiod is not affected by climate change whereas temperature is, especially in temperate and boreal zones and particularly in the winter more frequently than in the summer (Hodkinson, 2005). Evidence may be obtained by demonstrating that conditions exceeding the currently observed thresholds of species survival will either impose prohibitive mortality, or preclude the completion of the life cycle.

The winter pine processionary moth, Thaumetopoea pityocampa (Lepidoptera, Notodontidae), provides a classic example of an insect feeding on mature foliage that does not need to be synchronized with 
the spring leaf flush. In addition, the larvae feed during the winter, usually while in the third to fifth instar, and respond positively even to a slight increase of temperature (Battisti et al., 2005). As Th. pityocampa is univoltine, favourable conditions could promote faster development and thus the possibility to develop continuously. Larvae are night feeders and gregarious, with a development time in the field varying between four and nine months (Démolin, 1969; Battisti et al., 2015), depending on the winter conditions. The timing of adult emergence is generally inversely proportional to the length of the larval development, i.e. populations with early adults show the longest larval development, and vice versa (Démolin, 1969; Battisti et al., 2015). A phenological plasticity is typical among populations of this species, being considered as an adaptive strategy to the wide gradients of latitude and elevation over which Th. pityocampa range extends. Such plasticity consists of a complementary duration of the larval and pupal stages, for example a long feeding period coupled with a short pupal development in cooler areas and vice versa (Huchon \& Démolin, 1970).

Interestingly, in 1997 a population with shifted phenology was discovered in Portugal, which is characterized by larval feeding in the summer, instead of in the winter. In this population, the adults emerge in the late spring (April-June), instead of in the summer (AugustSeptember), as locally observed for the typical populations. Previous research established that the shifted population is genetically differentiated from the sympatric winter pine processionary moth (Santos et $a l ., 2007 ; 2011 \mathrm{a}$ ). The summer and winter populations co-occur in the same area, being however to a large extent isolated, due to asynchronous reproductive periods (Santos et al., 2011a).

Considering that Th. pityocampa presents a large phenotypic plasticity regarding the duration of the different life stages, it would be important to determine its development under constant laboratory conditions. Although the pine processionary moth was reared by many entomologists under controlled conditions, in the literature two data sets only are available. The first one relates to a population of the winter feeding Th. pityocampa from Kassandra peninsula, in northern Greece (Devkota \& Schmidt, 1990). This population was collected in the egg stage and transferred to a laboratory in Germany (Hannover) where it was raised at 17$20^{\circ} \mathrm{C}$. Adult emergence was observed exactly one year later, although larval development lasted between 86 and 109 days only. The second data set concerning another Greek population from Kalogria (southern Greece) provided similar results (Schmidt, 1990; Douma-Petridou, 1990). The difficulty to rear urticating larvae which pose serious health risks to researchers, thus implying the availability of dedicated rearing chambers (Battisti et al., 2011), probably contributes to explain this gap.

Therefore, the objective of this study was to obtain fundamental data pertaining to the duration of Th. pityocampa development under controlled conditions. We had access to two independent data sets which are collated in this paper in order to provide the reader with the first synthesis on the development time of the pine processionary moth under laboratory conditions. Four distinct populations were studied, two from Italy characterized by winter feeding and early versus late moth emergence in the field, and two from Portugal characterized by summer versus winter feeding. Although methods differed between the two data sets available, findings allow for comparisons in the duration of the developmental periods and mortality of the different life stages among populations having different phenology. Such knowledge may contribute to understanding the Th. pityocampa adaptation to different climatic conditions.

\section{Materials and Methods}

\section{Data set from Italy}

Populations previously identified in north-eastern Italy as having early and late moth emergence (Stastny et al., 2006) were selected for egg batch collection (early population: Cimolais, $12^{\circ} 27^{\prime} \mathrm{E} 46^{\circ} 19^{\prime} \mathrm{N}, 650$ $\mathrm{m}, 12$ egg batches collected in July 2012; late population: Cinto Euganeo, $11^{\circ} 39^{\prime} \mathrm{E} 45^{\circ} 16^{\prime} \mathrm{N}, 200 \mathrm{~m}$, and Tregnago, $11^{\circ} 09^{\prime} \mathrm{E} 45^{\circ} 30^{\prime} \mathrm{N}, 450$ m, 16 egg batches collected in August 2012). The population density of the pine processionary moth was very low at all sites.

The rearing was carried out in the laboratory of Padova University at Agripolis Legnaro at room temperature (average $22.0^{\circ} \mathrm{C}$, interval 20 $25^{\circ} \mathrm{C}$ ) and natural light. Egg batches of all populations were stored individually in plastic vials until hatching. All hatched larvae were transferred to aerated boxes (size $15 \times 10 \times 5 \mathrm{~cm}$ ) with freshly collected pine twigs carrying needles. After that, each egg batch was then cleaned from scales and the number of eggs and hatching holes counted. Colonies originating from different egg batches were reared in separate boxes. Pinus sylvestris was used instead of the original host $P$. nigra because the needles are shorter and easier to handle in the rearing boxes, while the larvae perform equally well on the two hosts (Stastny et al., 2006). The rate of larval mortality was calculated for each instar of each colony as the total number of dead larvae in a given instar over the number of larvae that entered that instar. At the end of the larval development, sand was added to the box to allow pupation. The boxes were inspected twice a week for the whole development period.

\section{Data set from Portugal}

Populations previously known to be characterised by larval feeding in winter and summer (Santos et al., 2007) on maritime pine Pinus pinaster in the National Forest of Leiria, Portugal $\left(39^{\circ} 47^{\prime} \mathrm{N}, 8^{\circ} 58^{\prime} \mathrm{W}, 50\right.$ $\mathrm{m}$ ) were selected for the laboratory rearing. Egg batches of both populations were obtained in the laboratory from late instar larvae collected in the field and reared to adult stage. Therefore, eggs were not exposed to parasitoids or harsh climate and egg survival was $100 \%$. Egg batches were obtained for five consecutive years, totalizing $12,6,46,46,52$ for the summer population, and 4, 34, 45, 60, 26 for the winter population, respectively. Number of eggs per egg batch ranged from 38 to 110. Egg batches were used to start the rearing in the laboratory of the University of Lisbon at room temperature (average $21.5^{\circ} \mathrm{C}$, interval 20 $24^{\circ} \mathrm{C}$ ) and natural light. Larvae from the same egg batch were fed in small cages with fresh maritime pine needles, which is the main host species in Leiria pine forest. Fresh twigs were provided every one or two days during the feeding period by gently removing the colony from the old twig, as well as the faeces and the feeding debris. Food was added ad libitum. On that occasion, the developmental stage as well as the larval mortality was checked. These observations were carried out at colony level, i.e. indication of the average instar of the larvae and whether or not the whole colony has died. The mean duration of each larval instar was calculated as the time when half of the larvae moulted to the next instar, excluding those that died during each specific period. The late fifth instar larvae were transferred to a box (size $25 \times 15 \times 5$ $\mathrm{cm}$ ) containing a bottom layer of $4 \mathrm{~cm}$ of sterilized sand, providing an adequate environment for pupation. About five weeks after pupation, the cocoons were sorted out from the sand and the pupae extracted. Each pupa was then kept individually in a plastic vial, under identical room temperature conditions. The pupae were inspected once a week until the beginning of the emergence of the moths, after which they were inspected daily.

\section{Statistical analyses}

To test for differences in the number of individuals and duration of development between Italian populations, a t-test was used. Differences in the developmental time of the colonies of summer and winter populations from Portugal were tested by one-way ANOVA. Mortality of Italian populations was compared with a $\chi^{2}$ test while that of Portuguese populations was analysed by logistic regression, considering the proportion of dead families as dependent variable and the factors population and larval stage. 


\section{Results}

\section{Data set from Italy}

The eggs of the Italian populations hatched in August in the early population and in September in the later one. The egg batches from the early populations had fewer eggs per batch $(225.2, \mathrm{SD}=50.0, \mathrm{n}=12)$ than those of the late population ( $251.7, \mathrm{SD}=35.4, \mathrm{n}=16)$, although the difference was not significant ( $\mathrm{t}$-test $=1.24, \mathrm{P}=0.23$ ) and the number of hatched eggs was similar for both populations (57.2, $\mathrm{SD}=19.9, \mathrm{n}=12$, and $65.1, \mathrm{SD}=36.3, \mathrm{n}=16$ for the early and late population, respectively) ( $\mathrm{t}$-test $=0.57, \mathrm{P}=0.58$ ). The remaining eggs did not hatch mainly because of egg parasitism which occurred in the field prior to collection.

The overall duration of the larval development did not differ significantly between the two populations (t-test=0.51, $\mathrm{P}=0.69$ ) (Table 1). Early instar larvae developed faster than later instars, with a slight variation between populations for each instar (Figure 1A). All mature larvae buried in the sand for pupation between December and January. The duration of the pupal development did not differ between the two populations ( $\mathrm{t}$-test $=0.45, \mathrm{P}=0.80$ ) (Table 1 ). The adults of the early population started emerging at the beginning of June and those from the late population one month later.

Larval mortality was associated with the arrest of feeding and the desiccation of the larvae. Symptoms clearly associated with microbial infections were not observed. For the early and late Italian populations, four out of 12 and four out of 16 colonies, respectively, reached the adult stage, although with few individuals. Larval mortality was rather high for the young larvae and declined progressively in the following instars (Figure 2), with no significant differences between the populations (test $\chi^{2}=4.3, \mathrm{P}=0.63$ ). Colony disappearance due to $100 \%$ larval mortality was not associated with a specific stage of development. Individual mortality in the colonies that survived to complete pupal development reached only $5.6 \%$ in the early and $11.3 \%$ in late population, that is much lower values than the mean colony mortality $71 \%$, calculated by pooling data for all colonies of both populations.

\section{Data set from Portugal}

Results of the five year monitoring of the Portuguese populations showed that eggs hatched from May $8^{\text {th }}$ to June $2^{\text {nd }}$ in the summer population and from August $3^{\text {rd }}$ to September $10^{\text {th }}$ in the winter population. Development thus began about three months earlier in the population with a shifted phenology, than in the typical one. The larval development in the summer population was significantly shorter than in the winter population $\left(\mathrm{F}_{1,53}=39.07, \mathrm{P}<0.001\right)$ (Table 1). Accordingly, the duration of instars was also shorter in the summer population (Figure 1B). For the summer population, all surviving larvae pupated during the months of August and September while in the winter population they pupated between the second week of November and the end of
December. Emergences occurred from the first week of May to the end of June in the summer population, and from the end of July to midAugust in the winter population. Therefore the pupal stage was significantly longer in the summer population than in the winter population $\left(\mathrm{F}_{1,36}=14.35, \mathrm{P}=0.001\right)$ (Table 1).

Larval mortality, estimated at colony level only, was higher for the early
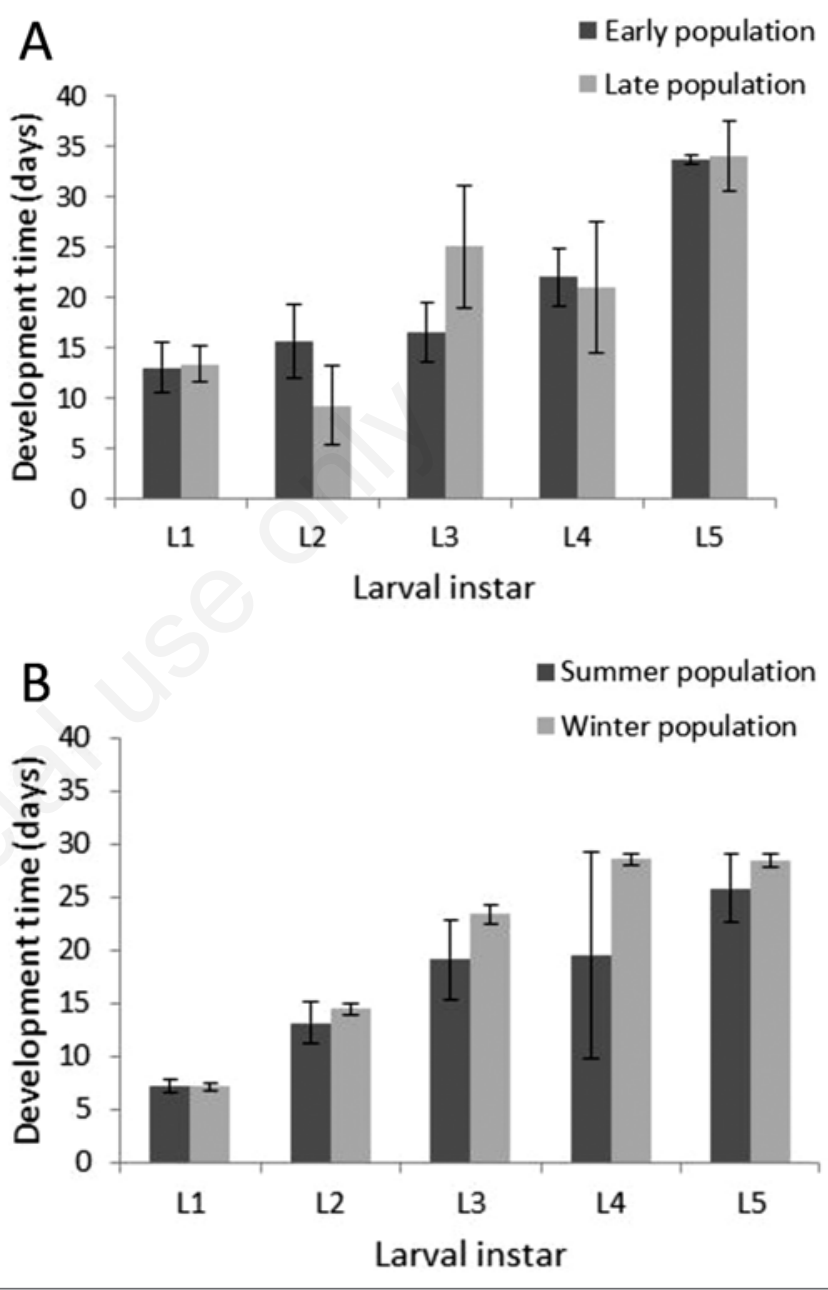

Figure 1. Duration of larval development of each instar of early and late populations of Thaumetopoea pityocampa from the Italian Alps (A) and of summer and winter populations of Thaumetopoea pityocampa from Portugal (B). Bars indicate standard deviation. Numbers of colonies are given in the text.

Table 1. Duration of larval and pupal development of populations of Thaumetopoea pityocampa under laboratory conditions. Data from literature are added $(*)$.

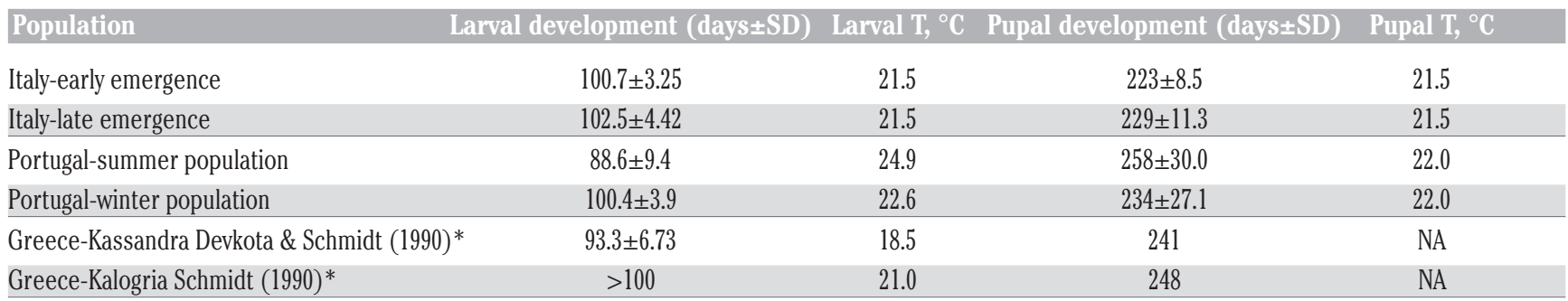

SD, standard deviation; NA, not available. 
than for the late instars in the summer population (Wald $\chi^{2}=12.94$, $\mathrm{P}=0.012$ ), while it was similar across instars in the winter population (Table 2). Marginally significant differences between populations were found on the larval stage (Wald $\chi^{2}=3.60, \mathrm{P}=0.058$ ), with higher mortality in the winter population, which was particularly strong in the pupal stage $\left(\mathrm{F}_{1,41}=5.89, \mathrm{P}<0.01\right)$ (Table 2). The overall mean colony mortality during larval development, pooled from five years, was $64 \%$ and $72 \%$, for summer and winter populations, respectively.

\section{Discussion and Conclusions}

A striking result was achieved with the present work, namely that the pine processionary moth will maintain an annual life cycle even under conditions that could lead to continuous development. Raising larvae at a room temperature of $20-25^{\circ} \mathrm{C}$, either under short or long day-length, resulted in a developmental time variable between 88 and 102 days only, while larval development under field conditions usually takes between 180 and 300 days for the winter feeding populations and around 90 days for the summer feeding populations (Battisti et al., 2015). The maintenance of an annual life cycle is therefore made possible by a flexible duration of the pupal stage, which in the typical and widespread winter feeding populations was much longer under laboratory conditions than in the field. In addition, the duration of the pupal stage can be much longer in the field in case of prolonged diapause, while such an extension has never been reported under laboratory conditions for this species.

For the typical winter populations, the duration of the larval period has been shown to be strictly dependent on temperature, since continuous larval feeding takes place as long as two conditions are met: night temperatures above $0^{\circ} \mathrm{C}$ and previous day temperatures remaining above $9^{\circ} \mathrm{C}$ inside the tent (Battisti et al., 2005). In addition, colonies may cope with extended periods of starvation and repeated freezing across the winter (Hoch et al., 2009). Interestingly, the switching to summer feeding recently observed in Portugal (Santos et al., 2007; Santos et al., 2011a), resulted in larval and pupal developmental times

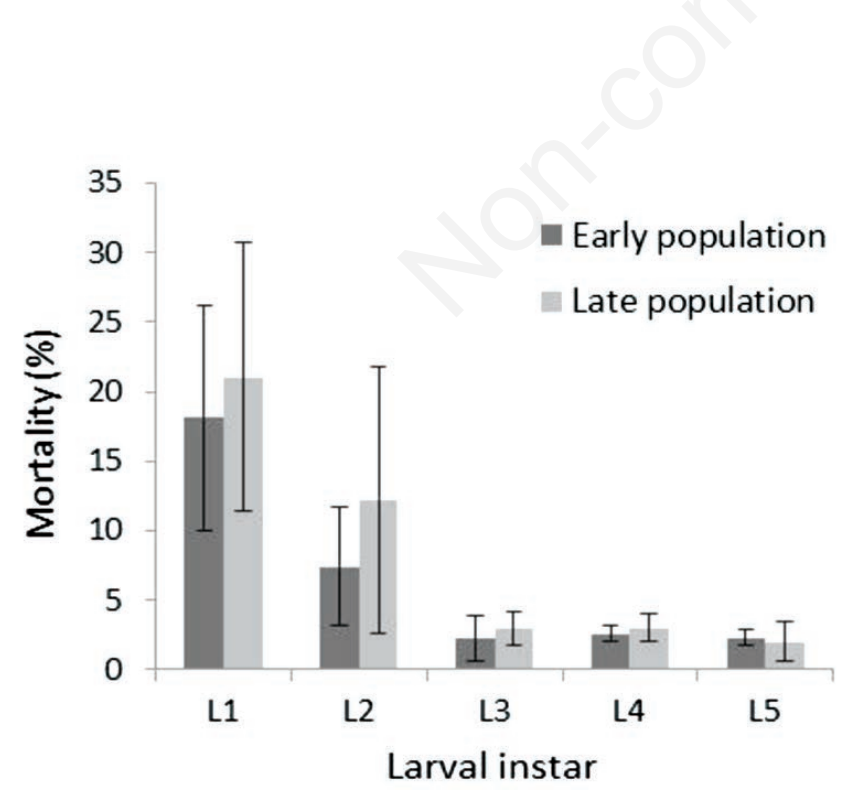

Figure 2. Average individual mortality of larvae of early and late Italian populations of Thaumetopoea pityocampa. Mortality has been evaluated by counting all the individuals which died in a given instar in each colony. Bars indicate standard deviation (number of starting colonies: 12 for early and 16 for late populations). which resemble those obtained in the laboratory, at $20-25^{\circ} \mathrm{C}$, for the winter populations. This agrees with the fact that average monthly temperatures are normally within $20-25^{\circ} \mathrm{C}$ during larval development of the summer population. Thus, it seems that the timing of adult emergence is regulated by factors which are relatively independent from temperature and determined by the pupae diapause, while the duration of both the adult and egg stages does not show major variations among populations (Battisti et al., 2015).

Data obtained from laboratory rearing confirm the general pattern described by Démolin (1969), based on the collation of a large number of observations across elevation and latitude gradients. According to this author, a negative association can be observed between winter temperatures and the duration of larval development and a positive relationship with the length of the pupal stage. Such a mechanism is basically dependent on variations of the timing of adult emergence, which can extend over several months depending on the location, as confirmed by the survey of Pimentel et al. (2010).

Data available for six populations of Th. pityocampa reared under laboratory conditions show little variation regarding the duration of the period of larval development at room temperature, in spite of their different geographic origins. Still, slight variations observed in the laboratory may be in part justified by differences in temperature. Although the correlation was not significant, developmental time tended to decrease with increasing temperature $(\mathrm{r}=-0.27, \mathrm{P}=0.61)$, consistently with the expected effect of temperature on larval development which is generally observed in the field. Such results are in accordance with the general predictions of temperature-based models of insect development (Chapman, 1998).

Within the larval stage, longer durations of the L3, L4, and L5 instars were observed with respect to the first two instars. The higher biomass of the later instars may justify their longer development time, as the biomass of L5 larvae may be 22 times greater than that of the L2 (Branco et al., 2008). For all larval instars, the developmental time was shorter in the summer population than in the Portuguese winter population. This result might be justified by slight temperature differences between the two periods (Table 2). Otherwise, we can hypothesize that the higher egg size found in the summer population, compared to that of the winter population (Santos et al., 2013), may have an adaptive significance resulting in lower mortality and shorter development time (Zovi et al., 2008). Quantitative and/or qualitative variations of the diet could also have affected larval development, as low growth rates are associated with poor diets (Chapman, 1988). However, this does not seem to be the case of the studied populations, as they were raised on a preferred host species and regularly provided with fresh pine twigs.

The pupal development times show much higher variation which does not seem to be explained by temperature. This physiological

Table 2. Average colony mortality percentage (\%) of larvae and pupae of the Portuguese populations of Thaumetopoea pityocam$p a$. The averages indicate the percentage of colonies which died in each instar during the five years of the study.

\begin{tabular}{lcc} 
Instars & $\begin{array}{r}\text { Summer population } \\
(\text { mean } \pm \text { SD })\end{array}$ & $\begin{array}{c}\text { Winter population } \\
\text { (mean } \pm \text { SD) }\end{array}$ \\
L1 & $32 \pm 3.6$ & $38 \pm 3.4$ \\
L2 & $32 \pm 4.4$ & $38 \pm 4.3$ \\
\hline L3 & $42 \pm 5.6$ & $30 \pm 5.2$ \\
L4 & $13 \pm 5.1$ & $24 \pm 5.7$ \\
\hline L5 & $18 \pm 6.1$ & $45 \pm 7.7$ \\
Pupae & $41 \pm 6.0$ & $69 \pm 10.2$ \\
\hline
\end{tabular}

SD, standard deviation. 
process is probably influenced by interaction between environmental, hormonal and genetic signals (Tauber et al., 1986; Danks, 1987; Denlinger, 2002) that lead to the maintenance of the univoltine cycle and emergence of the adults in the correct season similarly to what happens in the field, for each specific population. A recent study demonstrated that adults under laboratory conditions emerge one month earlier than in the field (Zhang et al., 1998). Still, in the present study the rearing was started from eggs and a good synchronization of the emergences times with those expected for the respective field populations was observed.

The percentage of mortality of Th. pityocampa larvae clearly decreased with the progression of the larval stages, although the causes of death could not be identified due to the lack of specificity of the symptoms. In the field, mortality is mostly due to pathogenic agents such as viruses, bacteria, and fungi. Pupae in the soil are mostly attacked by fungi which are a key factor causing the decline of the populations, especially in closed stands where soil moisture is high (Markalas, 1989; Battisti et al., 1998). However, the larval mortality assessed at individual level for the Italian populations of Th. pityocam$p a$ reflected the typical decreasing survivorship trend with larval growth (Speight et al., 1999). In the field, the young larvae of all populations are affected by a strong mortality, showing a direct influence from the daunting task of establishing themselves on a food plant (Zalucki et al., 2002). In the laboratory, the young larvae were found to have higher mortality in comparison with older larvae when exposed to disturbances such as thermal stress (Santos et al., 2011b).

Development times under laboratory conditions are also available for other species of Thaumetopoea. The larvae of Th. processionea of a population from Romania, were maintained at $20-22^{\circ} \mathrm{C}$ and developed in 76-79 days, instead of the 96-100 days observed in the field (Dissescu et al., 1968 in Battisti et al., 2015), although the annual life cycle was maintained. The larvae of Th. jordana developed faster in the laboratory than in the field and much faster at high temperatures, taking 70 days at $20^{\circ} \mathrm{C}, 48$ days at $25^{\circ} \mathrm{C}$, and 40 days at $30^{\circ} \mathrm{C}$ (Furth \& Halperin, 1979); still, in this case no anticipation of the adult emergence occurred. Studies of a Spanish population of Th. pinivora (Galapagar, Madrid, Spain) (Montoya \& Robredo, 1972) indicated similar developmental times in the laboratory as in the field although the extended diapause of the pupal stage was missing.

Although the available data were obtained under different conditions, it can be concluded that processionary moths are well synchronized with the seasonality of their habitats, despite the thermal variations that the larvae might experience, probably resulting from a long co-evolutionary process which has defined the development patterns. Yet, it is surprising that such pattern can be completely reversed, as in the case of the summer processionary moth of Portugal, while univoltinism is maintained. Since this event is considered to be recent, as far as the genetic distances indicate (Santos et al., 2007; 2011a), a large flexibility in the responses to environmental changes may be expected.

While the effect of temperature on larval development is quite clear, the mechanisms regulating pupal development need to be thoroughly considered. Due to the reduced metabolic activity of the pupal stage, it is likely that responses to temperature are different from those of the active phases. The flexible duration of the pupal stage ensures that most of the environmental stochasticity may be buffered. Therefore, it is expectable that a reliable signal, allowing the insects to break this stage and develop further, must have evolved. However, such signal cannot rely exclusively on temperature, due to the reduced thermal amplitudes experienced by the pupae in the soil. In short, the mechanisms regulating the physiology of diapause in Th. pityocampa must be further investigated, since this stage may provide the key to an understanding of the regulation of the phenology and thus the synchronization of emergences.

\section{References}

BATTISTI A., AVCI M., AVTZIS D., BEN JAMAA M., BERARDI L., BERRETIMA W., BRANCO M., CHAKALI G., EL ALAOUI M., FRFÉROT B., HODAR J., IONESCU-MALANCUS I., IPEKDAL K., LARSSON S., MANOLE T., MENDEL Z., MIRCHEV P., NEMER N., PAIVA M-R., PINO J., PROTASOV A., RAHIM N., ROUSSELET J., SANTOS H., SAUVARD D., SCHOPF A., SIMONATO M., YART A., ZAMOUM M., 2015 - Natural history of the processionary moths (Thaumetopoea spp.): new insights in relation to climate change. - In: ROQUES A., (ed). Processionary moths and climate change: an update. Springer-Quae, Dordrecht-Versailles, pp 15-80.

BATTISTI A., HOLM G., FAGRELL B., LARSSON S., 2011 - Urticating hairs in arthropods: their nature and medical significance. Ann. Rev. Entomol. 56: 203-220.

BATTISTI A., LONGO R., TIBERI R., TRIGGIANI 0., 1998 - Results and perspective in the use of Bacillus thuringiensis Berl. var. kurstaki and other pathogens against Thaumetopoea pityocampa (Den. et Schiff.) in Italy (Lep., Thaumetopoeidae). Anz. Schadlingskd. Pfl. 71: 72-76.

BATTISTI A., STASTNY M., NETHERER S., ROBINET C., SCHOPF A., ROQUES A., LARSSON S., 2005. Expansion of geographic range in the pine processionary moth caused by increased winter temperatures. Ecol. Appl. 15: 2084-2096.

CHAPMAN R.F., 1998 - The insects. Structure and function. Cambridge University Press, Cambridge, UK.

DAJOZ R., 2000 - Insects and forests: the role and diversity of insects in the forest environment. Intercept, Paris, France.

DANKS H.V., 1987 - Insect dormancy: an ecological perspective. Ottawa: Biol. Survey Canada.

DÉMOLIN G., 1969 - Bioecologia de la procesionaria del pino Thaumetopoea pityocampa Schiff. Incidencia de los factores climaticos. Bol. Serv. Plagas 12: 9-24.

DENLINGER D.L., 2002 - Regulation of diapause. Ann. Rev. Entomol. 47: 93-122.

DEVKOTA B., SCHMIDT G.H., 1990 - Larval development of Thaumetopoea pityocampa (Den. \& Schiff) (Lep., Thaumetopoeidae) from Greece as influenced by different host plants under laboratory conditions. J. Appl. Entomol. 109: 321-330.

DOUMA-PETRIDOU E., 1990 - European Thaumetopoea species (Lep., Thaumetopoeidae): characteristics and life-cycles. - In: SCHMIDT G.H., (ed). On the biology and control of Thaumetopoea spp. (Lepidoptera, Insecta), Department of Zoology-Entomology, University of Hannover (FRG), pp. 12-19.

EICHHORN 0., 1976 - Permanent culturing of Diprion pini L. with regard to photoperiodic conditions. Anz. Schadlingskd. Pfl. 49: 38-41.

FURTH D.G., HALPERIN J., 1979 - Observations of the phenology and biogeography of Thaumetopoea jordana (Staudinger) (Lepidoptera: Thaumetopoeidae). Isr. J. Entomol. 13: 1-11.

HOCH G., TOFFOLO E. P., NETHERER S., BATTISTI A., SCHOPF A., 2009 - Survival at low temperature of larvae of the pine processionary moth Thaumetopoea pityocampa from an area of range expansion. Agr. For. Entomol. 11: 313-320.

HODKINSON I.D., 2005 - Terrestrial insects along elevation gradients : species and community responses to altitude. Biol. Rev. 80: 489-513.

HUCHON H., DÉMOLIN G., 1970 - La bioécologie de la processionaire du pin. Dispersion potentielle, dispersion actuelle. Rev. For. Franc. nombre spéciale 'La lutte biologique en forêt', pp. 220-234.

LARSSON S., BJÖRKMAN C., KIDD N.A.C., 1993 - Outbreaks in diprionid sawflies: why some species and not others?. - In: WAGNER M.R., RAFFA K.F., (ed). Sawfly life history adaptations to woody plants pp. 453-483.

MARKALAS S., 1989 - Influence of soil moisture on the mortality, fecun- 
dity and diapause of the pine processionary moth (Thaumetopoea pityocampa Schiff.). J. Appl. Entomol. 107: 211-215.

MENU F., ROEBUCK J.P., 2000 - Bet-hedging diapause strategy in stochastic environment. Am. Nat. 155: 234-724.

MONTOYA R., ROBREDO F., 1972 - Thaumetopoea pinivora, Tr. La processionaria de verano. Bol. Estac. Cent. Ecol.1: 43-56.

PIMENTEL C., FERREIRA C., NILSSON J.A., 2010. Latitudinal gradients and the shaping of life-history traits in a gregarious caterpillar. Biol. J. Linn. Soc. 100: 224-236.

SANTOS H., BURBAN C., ROUSSELET J., ROSSI J.-P., BRANCO M., KERDELHUÉ C., 2011a - Incipient allochronic speciation in the pine processionary moth (Thaumetopoea pityocampa, Lepidoptera, Notodontidae). J. Evol. Biol. 24: 146-158.

SANTOS H., PAIVA M.R., TAVARES C., KERDELHUE C., BRANCO M., 2011b - Temperature niche shift observed in a Lepidoptera population under allochronic divergence. J. Evol. Biol. 24: 1897-1905.

SANTOS H.M., PAIVA M.R., ROCHA S., KERDELHUÈ C., BRANCO M., 2013 -Phenotypic divergence in reproductive traits of a moth population experiencing a phenological shift. Ecol. Evol. 3: 5098-5108.

SANTOS H., ROUSSELET J., MAGNOUX E., PAIVA M.R., BRANCO M., KERDELHUÉ C., 2007 - Genetic isolation through time: allochronic differentiation of a phenologically atypical population of the pine processionary moth. P. R. Soc. London 274: 935-941.

SAUNDERS D.S., 1982 - Insect Clocks. Oxford: Pergamon.

SCHMIDT G.H., 1990 - Life cycle of Thaumetopea species distributed in different regions of Europe, North Africa and Near East. - In: SCHMIDT G.H., (ed). On the biology and control of Thaumetopoea spp. (Lepidoptera, Insecta), Department of Zoology-Entomology, University of Hannover (FRG), pp. 20-34.

SPEIGHT M.R., HUNTER M.D., WATT A.D., 1999 - Ecology of Insects: Concepts and Applications. Blackwell Science Ltd, Oxford.

STASTNY M., BATTISTI A., PETRUCCO-TOFFOLO E., SCHLYTER F., LARSSON S., 2006 - Host-plant use in the range expansion of the pine processionary moth, Thaumetopoea pityocampa. Ecol. Entomol. 31: 481-490.

TAUBER M.J., TAUBER C. A., MASAKI S., 1986 - Seasonal adaptation of insects. Oxford Univ. Press, New York.

WHITMAN D.W., AGRAWAL. A.A., 2009 - What is phenotypic plasticity and why is it important?. - In: WHITMAN D.W., ANANTHAKRISHNA T.N. (Eds). Phenotypic plasticity of insects: Mechanisms and consequences. Science Publishers, Inc, Enfield, NH pp.1-63.

ZALUCKI M.P., CLARKE A.R., MALCOM S.B., 2002 - Ecology and behaviour of first instar larval Lepidoptera. Ann. Rev. Entomol. 47: 361-393.

ZHANG Q.H., PAIVA M.R. 1998 - Female calling behaviour and male response to the sex pheromone in Thaumetopoea pityocampa (Den. et Schiff.) (Lep. Thaumetopoeidae). J. Appl. Entomol. 122: 353-360.

ZOVI D., STASTNY M., BATTISTI A., LARSSON S. 2008 - Ecological costs on local adaptation of an insect herbivore imposed by host plants and enemies. Ecology, 89: 1388-1398. 